\title{
Factors Affecting Domestic Tourism Promotion in Jordan: A Case Study of the Official Media
}

\author{
Ibrahim Kahlil Bazazo \\ Department of Travel and Tourism, Faculty of Tourism and Hospitality, The \\ University of Jordan, Amman, Jordan \\ Mohammed Riyad Al-Dweik \\ Department of Hotel Management, Faculty of Tourism and Hospitality, The \\ University of Jordan, Amman, Jordan \\ Emran Mohammad Almomani \\ Department of Food and Beverage Management, Faculty of Tourism and \\ Hospitality, The University of Jordan, Amman, Jordan \\ Ehab Abdul Raheem Alshatnawi \\ Department of Travel and Tourism Management, Faculty of Tourism and \\ Hospitality, The University of Jordan, Amman, Jordan
}

doi: 10.19044/esj.2016.v12n23p329 URL:http://dx.doi.org/10.19044/esj.2016.v12n23p329

\begin{abstract}
This paper deals with the impact of the Jordanian media in stimulating domestic tourism. When studied under various aspects, this study is deducted to evaluate the general trend of the official media and its role in increasing the size of domestic tourism in Jordan. The scientific case of this study is about the weakness of the Jordanian domestic tourism compared with the International Tourism. This is in addition to the official media's role regarding this issue. In this study, it had been concluded that the official media provides good results in the promotion of domestic tourism. Nevertheless, there are still many obstacles which continue to get in the way of the efforts which aim to develop and widen the prospects of domestic tourism in Jordan. The study pointed out a number of recommendations. One of the most important recommendations was that all media used for Tourism purposes in Jordan needs to be developed regarding the content, not the design. Also, the content should provide a real message about how an affordable domestic tourism can be appropriate and suitable for the Jordanian family. In addition, in-depth studies on the impact of the new media and its known tools to promote domestic Tourism should be developed.
\end{abstract}

Keywords: Domestic Tourism, Tourism Promotion Authority, Social Media, Official Media 


\section{Introduction}

Tourism is described as the future industry. It is one of the top three industries that constitute the force of the economics of services in the twentieth century. These three industries are: the telecommunications industry, the information technology industry, and the tourism industry. Tourism industry is unique because it is the fastest and the biggest regarding its growth process. These facts bring to Jordan many challenges in order to respond to the Tourism market. As a result, it requires more effort to achieve a real touristic revival that commensurate with tourism attraction in Jordan.

Jawabreh (2011) noted that tourism promotion through the Internet helps to increase competition in the prices of tourism, while tourism websites helps to provide information about tourism offers. Consequently, both sexes considers websites as a means of ensuring the information veracity of tourism offers.

The tourism industry is considered as one of the fastest growing and development sectors at an international level. This is as a result of its ability to generate employment opportunities, contribute to the gross domestic product, and provide hard currency. Many international reports issued by the World Tourism Organization (WTO) by the United Nations, indicate the increase of the international tourism growth. However, this was despite the exposure of the world to various economic crises. The number of tourists reached 25 million in 1950, 527 million tourists in 1995, and 1133 million tourists in 2014. Also, the income also increased dramatically as a result of the international tourism expenditure, and it reached 1245 billion US dollars in 2014. The World Tourism Organization predicts that the number of international tourist arrivals will reach about 1.6 billion tourists by 2020 (Annual Report, WTO, 2014).

During the last years, the Jordanian economy has witnessed a fundamental shifts and changes in its future perspectives and development. The successive Jordanian governments gave priority to the tourism sector among the Industry plans and the governments. Therefore, they are always working hard to strengthen this industry as a distinctive center (center of Excellence) for the pig image of the Jordanian industries. Where the tourism industry is and will remain a long-term motive to enhance the economic growth in Jordan, they will have the largest share of GDP in Jordan's economy production. Jordan has witnessed a steady increase in tourism during the first of the twenty-first century. Thus, more than seven million passengers arrived Jordan in 2011 and spent more than two billion Jordanian Dinars. As such, this contributed to more than 14.2\% of the GDP. According to the statistics provided by Tourism and Antiquities Ministry in Jordan, direct employment in the tourism sector has reached 42,500 jobs in 2011 (Jawabreh, 2014). 
Subsequently, it was discovered that the hotel in Aqaba use specialized Customer Relationship Management (CRM) software to manage customers. In addition, the hotel makes use of specialized Customer Relationship Management (CRM) Software to improve its ability to manage customers. This continues to the extent that staffs have to follow some specific guidelines to work together as a team.

Therefore, it was estimated that this supported the creation of hundreds of thousands of similar jobs in the economic sector when calculating the overall multiplier effect. In this context, the big concern and interest in this sector had emerged. Thus, the first strategic objective of the Jordanian kingdom is to establish a modern tourist industry which is being developed and advanced according to the highest international standards and specifications (National Strategy for Tourism, 2011 to 2015).

\section{Previous Studies}

The managerial and administrative literature is full of studies that deal with domestic Tourism, media and tourism etc. In 2013, Mohammed Al Qasimi conducted a study on the title "The role of tourism media in creating a spot for Dubai on the world tourism map." Thus, his study deals with the importance of Mall tourism (Shopping tourism) and the role of the local and universal media in focusing on Dubai Shopping Festival and tourists being attracted from all over the world to visit Dubai. The researcher of this study highlighted the importance of a specialized tourism media which commensurate with the available tourist attractions. The study pointed out the importance of adopting and promoting digital tools for promoting tourist sites.

Reiodas (2013) and Al Omari (2015) studied the impact of social media in stimulating domestic tourism in Greece. The study confirmed that social media is directly contributing to the increase in the market share. This is with the aim of directing and stimulating tourism into the country "due to its essential role in developing and flourishing tourism." Social media is creating tourism awareness, especially about the archaeological sites available in Greek and they work to strengthen their respect for these sites.

Another study entitled "The Role of Tourism Information in the Promotion of Tourist Product of Tunisia” was conducted by Maher Othman (2012). This study aims to indicate the role of the media in the Development of tourism in Tunisia after the Arab Spring events. This was done by focusing on the latest distinctive media tools that specializes in the promotion of tourism product in Tunisia. The study indicates that there is a real importance for the Tourism media where its main purpose is to attract the largest possible number of tourists on the local and global level. In 
addition, it also aims to work on enhancing the tourist's perspective about the benefits gained by developing the Tunisian tourism product.

In 2011, Mohammad ALsarayreh, Omar A. A. Jawabreh, Khalid ALkharabsheh, and Mohammed Aldahamsheh conducted a study titled "Tourism Promotion through the Internet (Websites)." Their research paper seeks to study the status of tourism promotion in Jordan, in particular via the Internet. The aim of this research paper is to draw conclusions that help to know and understand this type of tourism promotion, and how to develop it in the Hashemite Kingdom of Jordan to disseminate the maximum information about Jordan. The findings and recommendations implied by this research paper will be presented to decision-makers in Jordan tourism sector to be taken into account.

\section{Importance of Media in Developing Jordan's Tourism Economy}

Many media institutions in the current era are seeking to prove themselves and establish an unparalleled reputation. This they do by providing the best services they got, such that their services will exceed the consumers' expectations and need. For Media institutions, providing the best is the key element to progress and excellence over its competitors. This is because the current media environment has become an environment characterized by fast growth and change. From here, the media institutions have become obligated to search for everything that can fulfill her strategies in various methods and techniques. This, however, help them to achieve the highest performance and levels of excellence in reaching the highest levels of customer's satisfaction. As the client become the center of interest, the care and focus of many media organizations are trying to attract him/her in various ways and means (Kefah et al., 2015).

Quality management has become one of the subjects that have received a wide attention within the media institutions of different types and sizes. This is because quality management philosophy focuses on the customers and how to meet their growing needs and desires. Also, it focuses on the need for integration of activities and functions within the same media organization. Quality management also focuses on continuous improvement in all work's aspects and places emphasis in educating all employees working in the media institutions as a basis for excellence and superiority (Omar et al., 2012).

Consequently, there is no doubt that the implementation of the total quality management's principles can enhance the level of quality of services which must meet the needs and expectations of the media organization, weather at the local or regional level.

The importance of quality management in the tourism media and its role in stimulating domestic tourism is still immature. From here, the main 
problem is that the actual implementation of quality management necessarily requires the employees being able to recognize the importance of applying the principles of quality management.

The concept of quality management in the tourism media is considered to be one of the modern concepts that aim to improve and develop the media industry in a sustainable manner. This can be accomplished by responding to the requirements of tourists and by satisfying their needs. It should be noted that it is difficult to provide a specific definition of quality in the field of tourism media. However, it is based on these two concepts:

1. Leadership: This means providing advanced and innovative media services that meet the needs of tourists.

2. Franchise: This means achieving balance between the requirements of the tourist and the general components of satellite channels. As a result, this enhances the performance of employees in these media channels.

One of the most important dimensions of tourism media industry is the Technical Competence. Hence, this has to do with the skills, abilities, and the level of the actual performance in satellite channels management, as well as the smooth and easy way to access the media sites. This means that any media service provided must not be bounded, but should be easily accessible and be close and available with all means of communication. Applying quality standards in the tourism depends on:

1. The principle of effectiveness and impact, where the quality is determined by the effectiveness and the impact of media services provided based on scientific grounds, and in providing an appropriate technology in a way. services.

2 .Efficiency, which means being efficient in presenting Media

3. Continuity, which means providing media services based on the sustainability principles without interruption or outage.

The quality management in the tourism media industry rules means the development and the conservation of the possibility of satellite channels tourism in order to improve the quality of service provided to tourists continuously and sustainably. It also aims to meet the tourists' needs, ending with evaluating whether the tourists are satisfied with the services or products offered to them. Furthermore, it ensures a continuous development of quality, productivity, and efficiency with the integration of quality with the strategic planning of management.

The success of the implementation of quality management principles necessarily depend on how much the senior management are convinced, its commitment, and its support towards the total quality approach in tourism media institutions. As a result, the senior management in tourism media must 
sponsor the application of TQM (Total Quality Management). Hence, this can be achieved through creating unites that deals with QM in media institutions. These unites' contact with the Team management will represent a connection with other managerial levels. Thus, this would enable us to ensure the implementation of TQM plans and strategies in a better way. It is important to focus on such concepts between the staff in these kinds of institutions. It is incorrect to focus on some principles and ignoring some others. They are all connected to each other, and the focus on the principle that encourages the treatment of tourist as our interest and attention center is the most important. The tourists are the main center of TQM, and we can achieve that by listening to them to identify their needs and expectations more.

Reaching a high level regarding the tourism media services quality is a result of co-collaborative efforts between the staffs. Thus, it is a must to recognize such concepts and encourage them to work as a team, especially as our focus is on the media. This requires the creation of a means of communication between the staff and the managers. It adds to this to engage all different managerial levels in the operation to get better result and success. QM means full comprehensiveness and the complete engagement of all stakeholders without any exceptions.

\section{The Importance of the Study}

1. The study shows the importance of the tourism sector in Jordan, which forms the backbone of the national economy by $14.7 \%$ of the income of Jordan (The Central Bank, 2013).

2. Domestic tourism in developed countries has the majority of tourist activities, and they represent about $90 \%$ of the total tourist activity in these countries. In turn, these can only means that the international and regional tourism contribute about $10 \%$ of the total tourist activities at the international level.

3. The importance of tourism media performs a role in influencing and directing the domestic and international tourist movement, by which it fits the potentiality of countries.

4. The relationship between the media and tourism is described as a relation that is full of correlation and harmony. Thus, the more the interaction, the more better the result we get based on all levels such as scientifically, culturally, and economically.

5. The results of this study will assists tourism planner and marketer to be introduced to the importance of the media regarding the tourism movement.

6. This study will enrich the theoretical literature in both fields of media and tourism. 


\section{The Problem of the Study}

The role played by domestic tourism in tourist activity is still limited in Jordan, and this suggests that domestic tourism contribution in Jordan's tourism industry is still bounded. In the past decade, the domestic tourism contribution in the Kingdom was almost 7\% out of the total tourist activities. Therefore, this requires the need to double the public-private sector efforts to expand the contribution of tourism media in stimulating and encouraging domestic tourism to support the tourism activity in Jordan. This is done through the distinctive tourism media. These difficulties are, however, linked to these constraints weakness of cultural awareness toward the value of these sites and tourist attractions. This was seen as the limited and weak media programs that target different categories of Jordanian society. In addition to this, we can add the weakness of the motivations and benefits needed to enhance domestic tourism. From analyzing the national strategy which was set for the development of Jordan's tourism sector for the years 2011-2015, it has been concluded that this strategy is empty of any kind of the development of the Tourism media that deals with the domestic tourism. Furthermore, this indicates the importance of reviewing this strategy to develop and support the concept of appropriate tourism media.

\section{The Objectives of the Study}

The study aimed to identify the effect of the Jordanian official media to stimulate domestic tourism. This was fulfilled through the identification of the following objective:

1. The importance of the Tourism media that deals with the improvement of domestic tourism.

2. State the weaknesses in the tourism media in Jordan and propose the best mechanisms to raise its efficiency.

3. Build a partnership with the media, working to strengthen its capacity to deliver messages related to domestic tourism issues, and to consider the media as one of the tourism development tools which help to highlight those issues in the public dialogue in order to influence tourism policy-makers.

4. Create media networks that work to widen the awareness of tourist sites in Jordan. This is done through monitoring and exchanging information about the good management, encouraging the exchange of expertise and experiences among network members, and giving the educational qualification to people who work in the field of Tourism media on how to use modern technical means. 


\section{Methodology of the Study}

The methodology used by the researcher entails designing the study and determining the study sample, tool and method of preparation, and the implications of validity and reliability, as well as the process of data collection and analysis. Therefore, this is in addition to the statistical treatments used in the analysis.

\section{The Hypotheses}

1. There are no statistical significant differences in the averages of the quality of the performance of the official Jordanian media (Jordanian TV), and the development of domestic tourism pattern in Jordan at the level of significance $(0.05, \geq a)$.

2. There are no statistical significant differences in the averages of the quality of the Jordanian official media (the Tourism Authority) performance, as well as the development of domestic tourism pattern in Jordan at the level of significance $(0.05, \geq a)$.

\section{Study Design}

The design that deals with scientific studies depends on the nature of the issued problem and the aims which are expected to be achieved when the analyses and treatment of the whole problem has been completed. The researcher used the descriptive analytical method, supported by field visits and studies strategy that is considered the most harmonious in order to fulfill the current study. The researcher also used some references and available resources to prepare the theoretical framework for the study. In the field side, the researcher used a questionnaire as the primary means of data collection and statistical analysis to get to the analysis of the assumptions for the study. The process of forming the questionnaire has been decided through the literature review that has to do with tourism and media management, as well as a review of previous studies and researches. This is done through discussions with a large number of academics and Tourism experts. In addition to the researcher's own experience in this field, the tools were subjected to both validity and reliability tests.

Likert scale was adopted (scale with closed questions) from 5 to 1 , which expressed the degree of the approval. Here, the given value (5) was given to indicate the strong approval, value (4) for approval, (3) for neutral, (2) for disagreeing, and (1) for strongly disagreeing. By redistributing the scale depending on the length of the category, the category's length equation is given as: (the largest reduction - smaller) divided by the number of categories, i.e. (5-1) $/ 5=4 / 5=0.8$. However, the table below shows the scale depending on the length of the category to the extent of the responder's 
approval, and the degree of assessing the performance level of the official media in developing domestic tourism.

Table 1.

\begin{tabular}{|c|c|c|c|}
\hline The Scale's Value & Category's Length & Agreement Degree & $\begin{array}{c}\text { Performance } \\
\text { Evaluation }\end{array}$ \\
\hline 1 & $1-1.8$ & Completely not agree & Very low \\
\hline 2 & $2.6-1.81$ & Not agree & Low \\
\hline 3 & $3.4-2.61$ & Neutral & Moderate \\
\hline 4 & $4.2-3.41$ & Agree & High \\
\hline 5 & $5-4.21$ & Strongly agree & Very high \\
\hline
\end{tabular}

Regarding the open questions used, the researcher depends on the recurrence pattern in inclosing the answers of the sub-categories provided by the study sample.

\section{Validity and Reliability Test}

Before adapting the questionnaire as a research tool by the researcher, including its questions, it was directed to different destinations. Thus, it was necessary to test the quality of scale through what is called the validity and validate tests (Validity \& Reliability). The reliable tool is the tool that measures what it was set for. The validity means the ability to achieve the measurements honestly. Therefore, we can differentiate between the Internal Validity and the External Validity of a tool. External validity of the tool is linked to the extent of the validity of the results that are achieved by using that tool. Also, it is associated in accuracy with the implementation of the tool which includes the accuracy of the study design and the accuracy in taking measurements or collecting data. Furthermore, this is achieved by providing a main explanation to the correlative relationships.

To measure the reliability factor, the Cronbach's alpha was used. Also, each study variable has been tested separately. This study's statistical fundamental (base) stated that the Percentage (ratio) accepted was 60\% or more (Sekearan). The result of the study's test is as shown below:

Table 2. Cronbach's alpha test results of the questionnaire study

\begin{tabular}{|c|c|c|c|}
\hline Number & Main Variables & Number of Variables & \\
\hline 1 & $\begin{array}{c}\text { Tourists' opinions about } \\
\text { Jordanian TV role in developing } \\
\text { the domestic tourism }\end{array}$ & 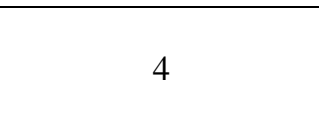 & 0.845 \\
\hline 2 & $\begin{array}{c}\text { Tourists' opinions about The } \\
\text { Tourism Board role in } \\
\text { developing the domestic tourism }\end{array}$ & 3 & 0.847 \\
\hline 3 & $\begin{array}{l}\text { Tourists' opinions about the } \\
\text { social media role in developing } \\
\text { the domestic tourism }\end{array}$ & 4 & 0.844 \\
\hline
\end{tabular}


From Table 2, we notice that the value of the Cronbach's alpha test factor for the first part of the questionnaire, which was directed towards the opinions of tourists about the role of the Jordanian television to encourage domestic tourism pattern and which contained 15 sub words (phrase), was high, statistically accepted, and its value was 0.845 . On the other hand, the value of the second part of the questionnaire, which contained 17 sub words directed towards the opinions of tourists about the Tourism board role in promoting tourism, reached 0.847 which is statistically acceptable too.

The value of the third part of the questionnaire, which was represented in six sub-phrases that is directed towards the tourists' perspective of the role of social media to develop domestic tourism, was 0.844. Therefore, there were no statistically acceptable differences. Generally, this means that the resolution was characterized by a high validity and reliable degree.

\section{Statistical Analysis Methods}

The SPSS has been implemented in order to carry out statistical analysis. Also, descriptive analysis tools had been represented by the Measures of central tendency like Averages, standard deviations, and the frequency tables were used also.

1. The one-way analysis of variance (ANOVA).

2. Pearson correlation coefficient, which ranges between the value $(-1$ - 1) to measure the strength between the variables and its directions.

3. Scheffe test to determine differences in the independent variables in favor of any samples.

4. Analyzing the statistical regression

5. Cronbach Alpha coefficient to measure the reliability and the validity of measurement tools.

\section{The Study Limitation}

- Human Barriers: The current study was limited to the Jordanian tourists.

- Spatial Barriers: Tourist sites included in the list of sites that contain tourist services were limited to the study of four main sites: Dead Sea, Petra, Jerash, and Aqaba. 2014.

- Time Barriers: The study was applied during the period of 2013-

\section{Test Hypotheses}

1- First Hypothesis Test 
HO: There were no statistically significant differences in the averages for the level of the Jordanian official media performance (Jordan TV) at the level of significance $(0.05, \geq a)$.

Table 3.

\begin{tabular}{|c|c|c|c|c|c|}
\hline Variable & & $\begin{array}{l}\text { Sum of } \\
\text { Squares }\end{array}$ & $\begin{array}{c}\text { Degrees of } \\
\text { Freedom }\end{array}$ & $\mathrm{F}$ & Sig \\
\hline \multirow[t]{3}{*}{ Documentaries } & $\begin{array}{c}\text { Between } \\
\text { groups }\end{array}$ & 2.747 & 2 & \multirow[t]{3}{*}{2.487} & \multirow[t]{3}{*}{0.107} \\
\hline & $\begin{array}{c}\text { Among } \\
\text { groups }\end{array}$ & 18.582 & 32 & & \\
\hline & Sum & 21.338 & 34 & & \\
\hline \multirow[t]{3}{*}{ Newscast } & $\begin{array}{c}\text { Between } \\
\text { groups }\end{array}$ & 0.41 & 1 & \multirow[t]{3}{*}{0.067} & \multirow[t]{3}{*}{0.797} \\
\hline & $\begin{array}{l}\text { Among } \\
\text { groups }\end{array}$ & 20.186 & 33 & & \\
\hline & Sum & 20.227 & 34 & & \\
\hline \multirow[t]{3}{*}{ Cinema Movies } & $\begin{array}{c}\text { Between } \\
\text { groups }\end{array}$ & 3.890 & 1 & \multirow[t]{3}{*}{7.858} & \multirow[t]{3}{*}{0.008} \\
\hline & $\begin{array}{l}\text { Among } \\
\text { groups }\end{array}$ & 16.337 & 33 & & \\
\hline & sum & 20.227 & 34 & & \\
\hline \multirow[t]{3}{*}{$\begin{array}{l}\text { Live shows } \\
\text { (programs) }\end{array}$} & $\begin{array}{c}\text { Between } \\
\text { groups }\end{array}$ & 20599 & 1 & \multirow[t]{3}{*}{4.865} & \multirow[t]{3}{*}{0.034} \\
\hline & $\begin{array}{l}\text { Among } \\
\text { groups }\end{array}$ & 17.628 & 33 & & \\
\hline & sum & 20.227 & 34 & & \\
\hline
\end{tabular}

The results were revealed by the analysis of variance test as follows:

1. There were no statistically significant differences in the averages for the level of Jordanian TV performance in stimulating domestic tourism due to the characteristics of quality and technical mastery at the level of significance $(0.05, \geq a)$. As the value $(\mathrm{F})$ was 2.397 and the value (Sig) which indicates to the significance level (0.107) is greater than the significance level approved for the study, the null hypothesis (HO1) was therefore accepted. This indicates that there were no statistically significant differences between documentaries variable and the stimulation of domestic tourism.

2. There were no significant differences in the averages for the level of The Jordanian TV in stimulating domestic tourism due to the characteristics of the newscast at the performance level $(0.05, \geq a)$. As the value (F) was calculated as 0.067 and the value (Sig) which indicates the significance level (0.789) is greater than the significance level approved for the study, the null hypothesis (HO1) was therefore accepted. This indicates the lack of statistically significant differences between the variable of the newscasts and the stimulation of domestic tourism. 
3. There were statistically significant differences in the averages for the level of the Jordanian TV performance in stimulating domestic tourism due to the Documentary Films at the level of significance $(0.05, \geq a)$. As the value (F) reached 4.606 and the value (Sig) which refers to the level of significance is .016, the null hypothesis (HO1) was therefore rejected. On the other hand, the alternative hypothesis was accepted which indicate the presence of significant differences between documentaries and the stimulation of domestic tourism.

4. There are statistically significant differences in the averages for the level of Jordanian TV in stimulating domestic tourism performance which is attributable to direct air programs at the level of significance $(0.05, \geq a)$. As the value (F) was 7.858 and the value (Sig) which refers to the level of significance (0.008) is less than the significance level approved for the study, the null hypothesis (HO1) was therefore rejected. On the other hand, the alternative hypothesis that indicates that the significant differences exist between the variable of Live programs and development of the domestic tourism was accepted.

Therefore, the following table shows the results of analyzing the contrast between the independent variables (documentary programs, newscast, live programs, movies etc.) and the dependent variable (domestic tourism development).

Table 4. Scheffe test's result for the Jordanian TV performance in stimulating and developing domestic tourism

\begin{tabular}{|c|c|c|c|c|}
\hline Scheffe & Variable & $\mathrm{N}$ & \multicolumn{2}{|c|}{ Subset for alpha $=.05$} \\
\hline$(\mathrm{a}, \mathrm{b})$ & & 1 & 2 & 1 \\
\hline & Documentaries & 89 & 3.876 & 7.98 \\
\hline & Newscast & 76 & 8.654 & 6.94 \\
\hline & $\begin{array}{c}\text { Live } \\
\text { shows(program) }\end{array}$ & 90 & 3.654 & 6.32 \\
\hline & Cinema movies & 54 & 2.451 & 5.76 \\
\hline
\end{tabular}

\section{Second Hypothesis Test}

HO: There were no statistically significant differences between the averages for the level of performance of the Jordan Tourism Board and stimulating the domestic tourism. Thus, this is due to e-newsletters, exhibitions, website, and conferences at the level of significance $(0.05, \geq a)$.

Consequently, the results revealed by the analysis of variance test were as follows:

1. The results of the analysis indicate that there are significant differences in the averages of the Tourism Board performance to promote and develop domestic tourism which is due to the characteristics of the electronic newsletter at the level $(0.05, \geq a)$. As the value $(F)$ was 4.876 and the value (Sig) that refers to the level of significance is 0.028 , the null 
hypothesis (HO1) is therefore rejected. On the other hand, the alternative hypothesis that indicate the presence of significant differences in the averages for the level of the performance of the Tourism Board in developing domestic tourism regarding the private variable of the enewsletters was accepted.

2. The results of the analysis indicate that there are significant differences in the averages of the Tourism Board performance dealing with the domestic tourism and that was due to the private variable of the establishment of exhibitions at the level $(0.05, \geq a)$. As the value $(F)$ calculated was 23.233 and value (Sig) which refers to the level of significance was 0.000 , the null hypothesis (HO1) was rejected. On the other hand, the alternative hypothesis that indicates the presence of significant differences in the averages of the level of the Tourism Board's performance in enhancing and developing the domestic Tourism according to the exhibitions' variable was accepted.

3. The results of the analysis indicate that there are significant differences in the averages of the Tourism Board performance dealing with the domestic tourism and that was due to the private variable of the websites at the level of significance $(0.05, \geq a)$. As the value $(\mathrm{F})$ was .871 and the value (Sig) which refers to the level of significance $(0.457)$ is greater than the level of the approved, the null hypothesis (HO1) was therefore accepted.

4. The results of the analysis indicate that there are significant differences in the averages for the level of performance of the Tourism Board because of the conferences at the level of significance $(0.05, \geq a)$. As the value (F) was 3.312 and the value (Sig) which refers to the level of significance was 0.012 , the null hypothesis (HO1) was thus rejected. On the other hand, the alternative hypothesis that indicates the presence of significant differences in the averages of the Tourism Board performance level according to the Conference variable was accepted.

The following table shows the results of the contrast analysis between the independent variables (e-newsletters, exhibitions, website, conferences etc.) and the dependent variable (active domestic tourism).

Table 5

\begin{tabular}{|c|c|c|c|c|c|}
\hline Variable & e-newsletters & $\begin{array}{c}\text { Sum of } \\
\text { squares }\end{array}$ & $\begin{array}{c}\text { Degrees of } \\
\text { freedom }\end{array}$ & F & Sig \\
\cline { 2 - 4 } & $\begin{array}{c}\text { Broups } \\
\text { Among } \\
\text { groups }\end{array}$ & 1.342 & 1 & \multirow{2}{*}{4.876} & 0.028 \\
\cline { 2 - 4 } & Sum & 54.495 & 198 & \multirow{2}{*}{23.233} & \multirow{2}{*}{0.000} \\
\hline \multirow{2}{*}{ exhibitions } & $\begin{array}{c}\text { Between } \\
\text { groups }\end{array}$ & 25.606 & 199 & \\
\cline { 2 - 4 } & $\begin{array}{c}\text { Among } \\
\text { groups }\end{array}$ & 30.231 & 192 & \\
\cline { 2 - 4 } & Sum & 55.837 & 199 & & \\
\hline
\end{tabular}




\begin{tabular}{|c|c|c|c|c|c|}
\hline \multirow{2}{*}{ Websites } & $\begin{array}{c}\text { Between } \\
\text { groups }\end{array}$ & 0.735 & \multirow{2}{*}{0.871} & 0.457 \\
\cline { 2 - 4 } & $\begin{array}{c}\text { Among } \\
\text { groups }\end{array}$ & 55.102 & 196 & & \\
\cline { 2 - 4 } & sum & 55.837 & 199 & \multirow{2}{*}{3.312} & \\
\hline \multirow{2}{*}{ Conferences } & $\begin{array}{c}\text { Between } \\
\text { groups }\end{array}$ & 3.552 & 4 & & \\
\cline { 2 - 4 } & $\begin{array}{c}\text { Among } \\
\text { groups }\end{array}$ & 52.285 & 195 & & \\
\cline { 2 - 4 } & sum & 55.837 & 199 & & \\
\hline
\end{tabular}

The following table represents the results of Scheffe test regarding Tourism Board efforts in developing domestic tourism:

Table 6.

\begin{tabular}{|c|c|c|c|c|}
\hline Scheffe & Variable & $\mathrm{N}$ & \multicolumn{2}{|c|}{ Subset for alpha $=.05$} \\
\hline$(\mathrm{a}, \mathrm{b})$ & & 1 & 2 & 1 \\
\hline & e-newsletters & 12 & 3.78 & 3.2 \\
\hline & Exhibitions & 87 & 1.87 & 3.1 \\
\hline & Websites & 83 & 0.99 & 1.9 \\
\hline & Conferences & 23 & 5.00 & 2.8 \\
\hline
\end{tabular}

Figure 3. The research sample distribution according to the age

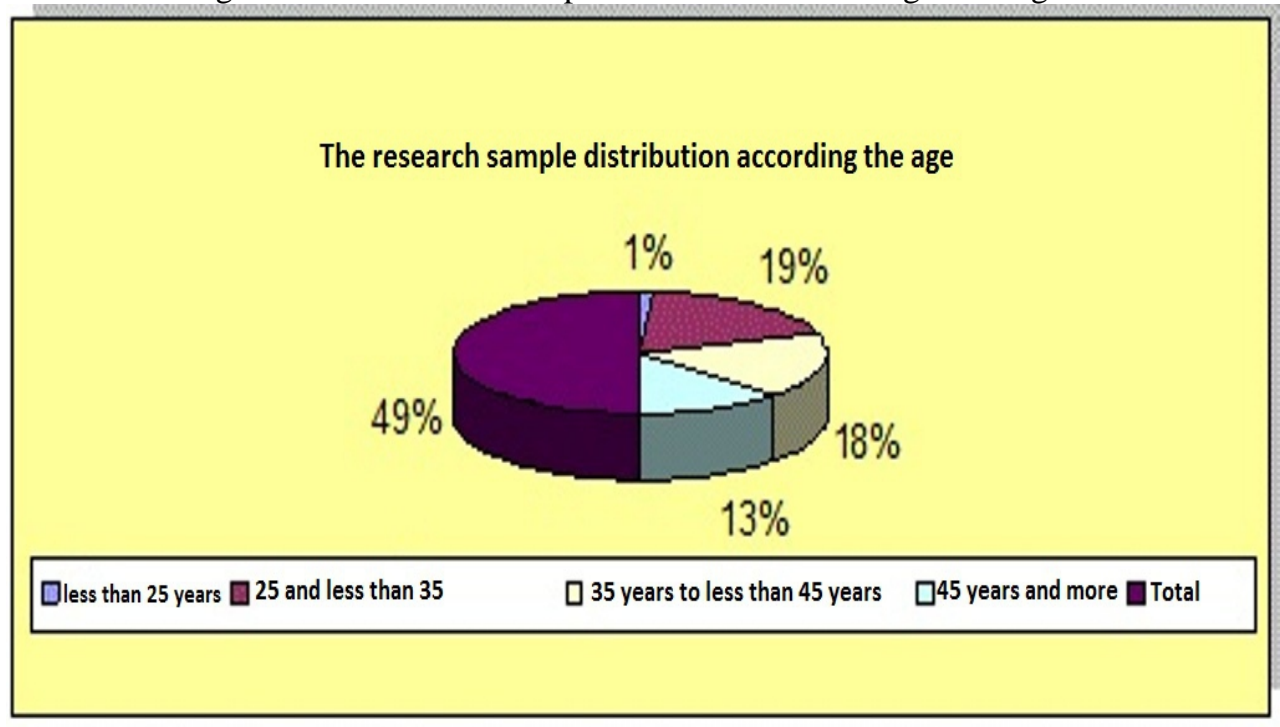

From Figure 3 above, it is clear that $2 \%$ of research sample were aged less than 25 years, 38\% of the sample were aged between 25 and less than 35 years, 35\% of sample were aged from 35 years to less than 45 years, and $25 \%$ of the research sample were aged by 45 years and more. By depending on that, we can conclude already that the research sample has great levels of ages which are good i.e. the youth age. Therefore, the performance is expected to be high. 
Figure 4. Sample analysis according to qualifications

\section{Sample analysis according to Qualifications}

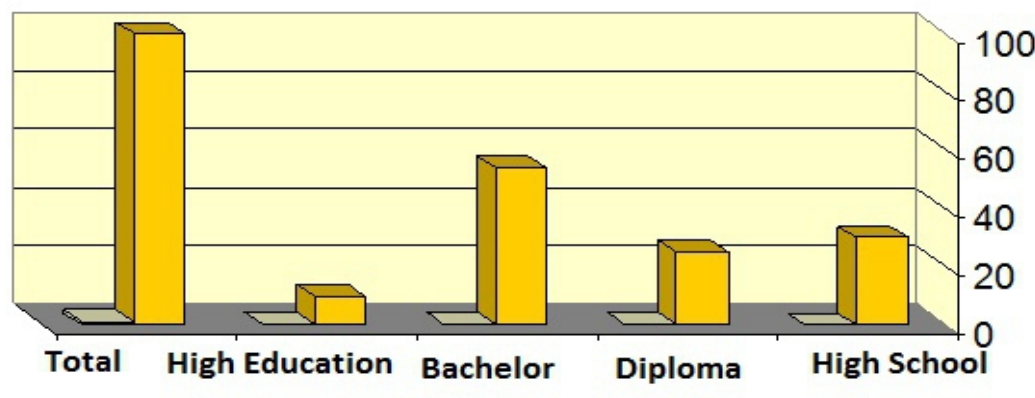

From Figure 4 above, it is clear that $20 \%$ of the research sample holds a diploma, $25 \%$ have high school certificate and less, $45 \%$ of the research sample holds their bachelor's degree, and $10 \%$ of the sample hold high education certificates. According to these data, it is obvious that more than half of the research sample hold bachelor's degrees. Thus, $10 \%$ of the sample holding High education certificates is a good indicator that the sample responses will be positive on the search phrases (questionnaire).

Figure 5. Sample analysis according to social status

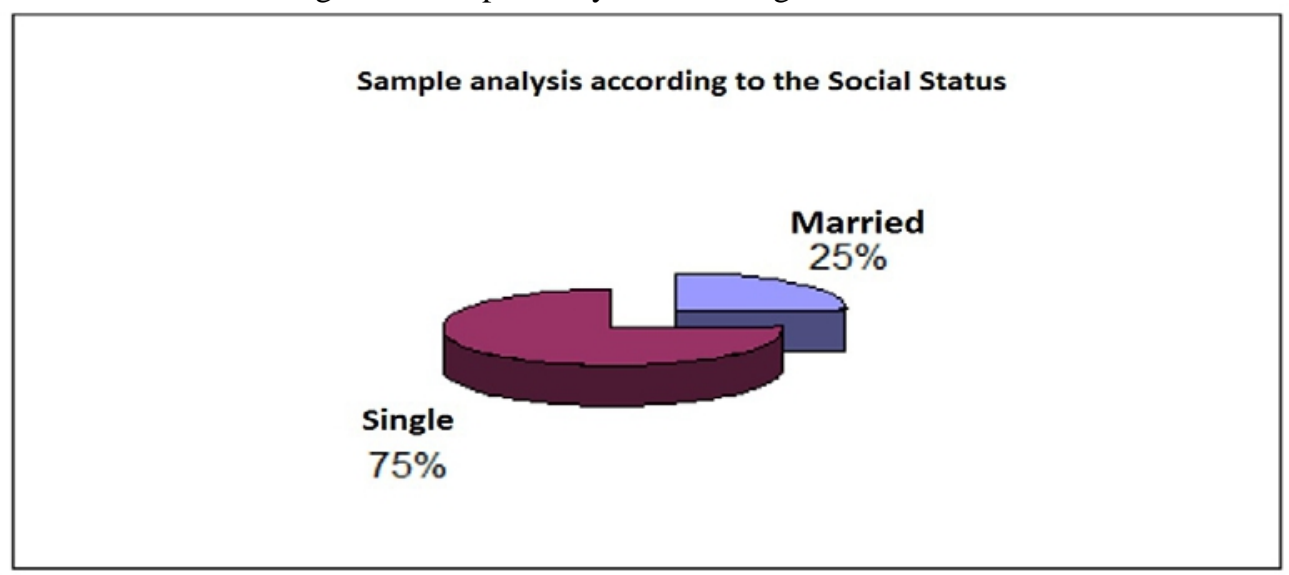

From Figure 5 above, it is clear that $75 \%$ of the samples are singles, while the other $25 \%$ are married. 
Figure 6. Sample analysis according to the work experience

Sample analysis according to the work experience

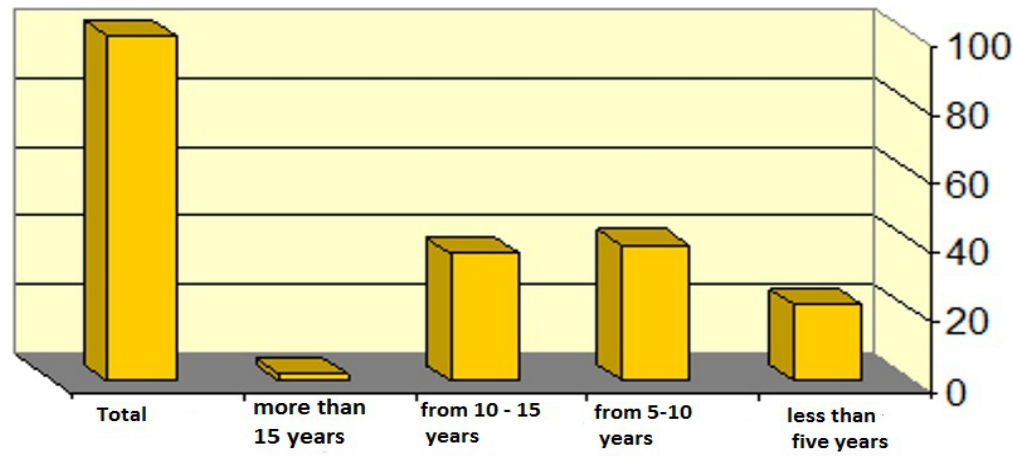

From Figure 6, it is clear that 2\% of the research sample got more than 15 years of work experience and that $22 \%$ of the sample got less than five years.

\section{Results}

Through the applied analytical study of the impact of the Jordanian official media in developing domestic tourism, the results show the following:

1. The importance of domestic tourism is reflected in many aspects and the most important one is to increase citizens' awareness of the importance of tourism for their country. However, Jordan is full of a number of natural attraction sites, breathtaking heritage, and archaeological and historical landmarks. Focusing on that will help to deepen the national identity affiliation. In addition, it would help to widen and increase community interaction (Local Communities) with tourism resources and attractions. According to that, attention must be targeted towards the tourism environment's preservation, the cleanliness of tourist sites, maintenance and protection based on sustainability factors, and the achievement of the integration of the international tourism and domestic tourism. On the other hand, both were considered as the tourism development base and the engine of economic activity. As a result, this led to further economic recovery in the tourism development areas by launching more projects, increasing the number of tourist facilities and tourism investments in tourism services, and creating more job opportunities in the current and new tourism areas. Also, we can fulfill this aim by encouraging the traditional handicrafts which reflect the forms and types of local heritage. 
2. Despite what has been referred to regarding the importance of domestic tourism in supporting the tourism activity, there are many obstacles and problems which continue to appear and tie up the efforts to develop the prospects of domestic tourism in Jordan. This is concentrated in the low income levels and standards of living for Jordanians. As a result, it limits their ability to spend money on tourism activities and the big size of the Jordanian families which reaches an average of about six people. As a result, it increases their savings difficulties and spending on tourism activities and facilities. This involves the multiple patterns of social life and relationsoriented mutual visits and hiking trips daily (short) to the wild nature areas like the Jordan Valley in the winter and the highlands in the summer, in addition to other forms of Hiking in public parks and on the outskirts of the main roads. In addition to that, there are cultural barriers represented in lacking the desire to visit the monuments and historic areas by the citizens

3. In the current era, a lot of media institutions are seeking to proving and promoting themselves by providing the best services of what they can present. As a result, these services exceed customers' satisfaction and needs. The provision of the best is the key element to progress and excellence over its competitors. This is because the current media environment has become an environment characterized by fast growth and change. From here, the media institutions have become obligated to search for everything that can fulfill her strategies in various methods and techniques in helping them to achieve the highest performance and levels of excellence for the purpose of reaching the highest levels of customer's satisfaction. Thus, this occurs as the client becomes the center of interest as a result of the care and focus of many media organizations who are trying to attract him/her through various ways and means.

4. There is a weakness in the capacity of promoting and developing domestic tourism because of the Tourism Board effort to promote the international tourism, and their lack of attention to activate domestic tourism on the other hand.

5. There is a weakness in the official tourism media capabilities to provide more deep analysis about domestic tourism issues and other general issues particularly about tourism, and the weakness of the media staff abilities while dealing with domestic tourism programs.

6. Media coverage tends mostly to rely on the news that covers the tourism sector instead of the full analysis of the issues involved. However, the people who work in tourism do not see the media as a partner in the development process, but they consider the media as a way to publish information. As a result, they are often marginalizing the role of the media when any domestic tourism initiatives were launched. 
7. The Official tourism media that is presented by the Jordanian TV and Tourism Board needs to be developed. Here, the study showed that $67 \%$ of the study sample believes that tourism media in Jordan is in a contrasting situation with the current status of tourism. This, therefore, requires the review of all the cases revealed in the tourism media. It takes away any exaggeration of any kind because it reduces the credibility of the vital media message carried by the tourism media.

8. The importance of quality management in the tourism media is still immature and ignored. From here, the main problem is that the actual implementation of quality management necessarily requires the recognizing of employees' recognition of the importance of applying the principles of quality management.

9. The results of the study showed that the rate of $2 \%$ of the respondents were aged less than 25 years, 38\% of the sample were aged between 25 years to less than 35 years, 35\% of them were in the age from 35 years to less than 45 years, and $25 \%$ of the sample were aged by 45 years and older. Thus, this indicates that the sample has a good age stages represented by young people.

10 . The result of the study indicates that $20 \%$ of the research sample holds a diploma, 25\% have high school certificate and less, $45 \%$ of the research sample holds their bachelor's degree, and $10 \%$ of the sample hold high education certificates. According to these data, it is obvious that more than half of the research sample hold bachelor's degrees, while $10 \%$ of the sample holds High education certificates. Hence, this is a good indication that the sample responses will be positive on the search phrases (questionnaire).

\section{Recommendations}

1. Reaching a high level regarding the tourism media services quality is a result of co-collaborative efforts between the staff. Thus, it is a must to recognize such concepts and encourage them to work as a team, especially now that we are talking about the media. This requires the creation of a means of communication between the staff and the managers. It adds to this to engage all different managerial levels in the operation for the purpose of getting better result and success. QM means full comprehensiveness and the complete engagement of all stakeholders without any exceptions.

2. Enhancing the official tourism media capabilities to provide its coverage in more depth, and also its analysis regarding domestic tourism issues. This adds to that working on organizing training courses given to people works in media in order to introduce them to the issues and the various tourist terminologies, and let them participate in proposing solutions. In addition to that, we must organize a regular media consultation that deals 
with tourism which is based on creating dialogues as a means of learning and knowledge exchanging. However, this is to be attended by media professionals and employees in the fields of development. The consultations have three main characteristics: dialogue, concentration of ideas, and partnership, as well as the people works in media can intervene in the dialogue and propose solutions and make a connection between experts and policy-makers who are responsible for the development process of ecotourism and the citizen.

3. Encouraging people who work in the media to attend and participate in various regional and international meetings which deals with domestic tourism issues. Here, these activities are aimed to help the media employees to identify their role by introducing and monitoring issues related to domestic tourism.

4. Merges local communities as an integral part of the tourism media programs because the practical and field studies have demonstrated their considerable influence upon the tourists' impressions. Therefore, the success of tourism programs in general is extremely important to pay attention to the locals, especially those who live in the tourist areas.

5. The content of all media's means and tools used in Tourism in Jordan need to be developed, and not the design. Also, the content must provide a realistic message about domestic tourism which has to be attractive.

\section{References:}

Al-Omari, Ali, RM Mahmoud, omar, \& Jawabreh (2015). The Arab spring impacts on the Jordanian hotels sector. International Journal of Humanities and Social Science,5,4,page 159-171.

Cooper \& Chris (2012). Tourism Principles and Practices, London, pitman publishing inc.

Foster \& Dennis (2010). Introduction to Travel and Tourism, N.Y, Wiley and sons.

Japan International Cooperation agency (JICA) (2013). National Tourism Development Strategy in Jordan, Tokyo, Japan.

Jawabreh (2014). The Impact of Customer Relationship Marketing by Aqaba Economic Zone "A Case Study of Five Stars Hotels", International Journal of Academic Research in Accounting, Finance and Management Sciences, vol. 4, issue 1, pages 167-174, DOI: 10.6007/IJARAFMS/v4-i1/583.

Kefah , Alshawagfih, Omar, Alananzeh, Omar, \& Jawabreh (2015). THE FOUNDATIONS OF SELECTING CULTURAL TOURISM PRODUCT IN JORDAN, European Scientific Journal, 11, 29.

Mohammad ALsarayreh, Omar A. A. Jawabreh, Khalid ALkharabsheh, \& Mohammed Aldahamsheh (2011). Tourism Promotion through the Internet 
(Websites) (Jordan as a Case Study), Asian Social Science, Vol. 7, No. 6; June, doi:10.5539/ass.v7n6p125.

Omar A.A. Jawabreh \& Ali Mahmoud Abdallah Alrabei (2012). The Impact of Accounting Information System in Planning, Controlling and DecisionMaking Processes in Jodhpur Hotels, Asian Journal of Finance \& Accounting,4,1, doi:10.5296/ajfa.v4i1.1435.

Tauseef \& Jawabreh (2012). Impact of Customer Relationship Management of Hotel (A Case study Umaid Bhwan), Asian Journal of Finance \& Accounting, Vol. 4, No. 1, doi:10.5296/ajfa.v4i1.1362.

Ministry of Tourism and Antiquities, Department of Statistics and Information, the annual report for 2014.

World Bank (2011). Second Tourism Development Project, Washington D.C, USA.

World Bank (2010). the Second tourism Development project in Jordan, Washington, USA.

World Tourism Organization (2015). Tourism Highlights 2015.

World tourism Organization (2011). Tourism 2020 Vision, Madrid. 